\title{
From donation to self-reflection: living of volunteers of a toy library for children with cancer
}

\author{
Da doação à autorreflexão: vivências de voluntários de uma brinquedoteca para crianças com câncer
} Desde la donación al autorreflexión: vivencias de voluntarios de una sala de juegos para niños con cáncer

Ana Paula Silva Pugliero ${ }^{1}$ Marcela Astolphi de Souza ${ }^{1}$ Luciana de Lione Melo ${ }^{1}$

1. Universidade Estadual de Campinas. Campinas, SP, Brazil.
Corresponding author:

Marcela Astolphi de Souza.

E-mail: marcela.astolphi@gmail.com

Submitted on $08 / 21 / 2017$

Accepted on 12/02/2017.

DOI: 10.1590/2177-9465-EAN-2017-0258

\section{Abstract}

Objective: To understand what it means to be a volunteer in a cancer-affected children care unit's toy library, located within the state of São Paulo. Method:Phenomenological study based on the assumptions related to the analysis of the stated phenomenon's structure, with eleven volunteers to be interviewed upon a guiding question: "What does it feel like to be a volunteer in a toy library used by children with cancer?". Results: From the volunteer's answers, three theme categories arose: self-oriented relations, group-oriented relations and world-oriented relations. Conclusion and implications for practice: Being a volunteer embraces diverse relationships that contribute to the self-knowledge of the individual, making it possible to review concepts, beliefs, values, according to the new times in which we live There is a need for volunteer empowerment for work as well as mental health care. Nurses play a fundamental role in this context.

Keywords: Volunteers; Play and playthings; Neoplasms; Child; Nursing.

\section{Resumo}

Objetivo: Compreender o significado de ser voluntário de uma brinquedoteca em uma casa de apoio para crianças com câncer. Método: Estudo fenomenológico a partir das premissas da análise da estrutura do fenômeno situado, com 11 voluntários entrevistados, a partir da questão norteadora: "Como é ser voluntário de uma brinquedoteca para crianças com câncer?". Resultados: A partir dos discursos dos voluntários emergiram três categorias temáticas: relações consigo, relações com o grupo e relações com o mundo, que foram analisadas à luz da literatura. Conclusão e implicações para a prática: Ser voluntário abarca relações diversas que contribuem para o autoconhecimento do indivíduo, possibilitando rever conceitos, crenças, valores, de acordo com os novos tempos em que vivemos. Há necessidade de capacitação dos voluntários para o trabalho e também cuidados com relação a saúde mental. O enfermeiro tem papel fundamental nesse contexto.

Palavras-chave: Trabalho voluntário; Jogos e brinquedos; Neoplasia; Criança; Enfermagem.

\section{Resumen}

Objetivo: Comprender el significado de ser un voluntario de una sala de juegos en una casa de apoyo para niños con cáncer Método: Estudio fenomenológico de las hipótesis del análisis de la estructura del fenómeno situado, llevado a cabo con 11 voluntarios entrevistados a partir de la pregunta: "¿Cómo es ser voluntariado de una sala de juegos para niños con cáncer?". Resultados: Emergieron tres categorías temáticas: relaciones con si mismo; relaciones con el grupo; y relaciones con el mundo. Conclusión e implicaciones para la práctica: Ser voluntario abarca relaciones diversas que contribuyen al autoconocimiento del individuo, posibilitando revisar conceptos, creencias y valores, de acuerdo con los nuevos tiempos en que vivimos. Hay necesidad de capacitación de los voluntarios para el trabajo y también cuidados con relación a la salud mental. El enfermero tiene un papel fundamental en este contexto.

Palabras clave: Voluntários; Juegos e implementos de juego; Neoplasia; Niño; Enfermería. 


\section{INTRODUCTION}

With the improvement of therapy, childhood cancer has become a chronic disease, reducing the connotation of irreparable death as in recent years, research shows that 70 to $80 \%$ of cases are successfully cured. ${ }^{1-4}$ Nevertheless, when compared to adults, it is considered to be harmful and invasive, rare in children and adolescents, however it is currently considered the leading cause of death due to illness in children over the age of five. ${ }^{5}$

Due to the long treatment and the difficult access to health services by the Brazilian population, including those specializing in cancer, children with cancer and their families can benefit from Programa do Tratamento Fora do Domicílio (The Out-of-Home Treatment Program TFD), instituted by Administrative order No. $55 / 99$ of the Ministry of Health, which offers treatment as well as financial support for necessities such as food, lodging and transport for the patient and family. ${ }^{6}$

Thus, the support houses for cancer patients were created, whose objectives are to offer accommodation, food, transport to the treatment site, social and therapeutic support to patients and their families, and other necessary services in view of the particular needs of each child. ${ }^{7}$

The child with cancer is faced with the imposition of numerous stressful experiences due to the invasive and complex treatment. ${ }^{2,8}$ Playing is something that is part of the child's world and allows the child to recycle their emotions, recuperate conflicting situations, and which favors imagination, selfknowledge, intellectual development, and the learning of moral values, ${ }^{9,10}$ which does not change when the child has cancer.

The child's experience of the illness and the treatment makes it imperative that the child has access to an ideal environment to vent the feelings caused by the new experiences. ${ }^{8,11}$ Thus, the support houses for children with cancer are considered scenarios that favor social interaction and promote their development, it allows the child to rediscover the pleasure of living, playing and socializing with their peers who are in the same health and disease situation. ${ }^{8}$

Therefore, the importance of toy libraries in hospital settings, outpatient treatment and support houses is evident. In addition, the time and environment in which the ludic activities are developed can constitute a therapeutic space for the child to understand of the disease better. ${ }^{11}$ These spaces usually have the support of contracted teams or volunteers, the latter being the focus of the present study.

In Brazil, in the 90's, with the growth of the third sector, voluntary work received specific legislation. Article 1 of Law 9608 of February 18, 1998 defines voluntary service as unpaid service, provided by a person, public and private non-profit entity, with civic, cultural, educational, scientific, recreational or social assistance purposes. ${ }^{12}$

Literature affirms that this type of work favors contact with the suffering of the other, providing benevolent experiences, where both benefit from the interaction. Several motivations both social and personal in nature can encourage a person to perform voluntary work. ${ }^{13-15}$
A study carried out with volunteers at a cancer hospital in India confirms that the motivations of these people are embedded in the need to help society to care for those who suffer. Other positive aspects are teamwork, the opportunity to share experiences and the offer of comfort and joy to others. ${ }^{16}$

Volunteer families who developed activities for people with severe mental illness were motivated by reasons such as understanding the need to help others and achieving something good for a vulnerable person, which generated feelings of joy and reward. ${ }^{17}$

To understand the experience of the volunteers of a toy library in a support house for children with cancer is a way to value the relationships that permeate the cancer treatment, in addition to highlighting the existing gap in voluntary work with sick children. Thus, it is believed that this understanding can increase the knowledge of those involved in this process regarding this type of work, but also so that the health team, knowing the experiences of the volunteers, can support their needs.

Therefore, the objective of this study is to understand the experiences of volunteers of a toy library for children with cancer.

\section{METHOD}

Phenomenology derives from the Greek terms logos which means 'speech that presents'; and phenomenon, 'that which appears by itself'. ${ }^{18}$ It is a research method that proposes the understanding of man in its totality, understanding that only those who experience the phenomenon are capable of describing it. ${ }^{19,20}$ The concept that similar phenomena are experienced by individuals in unique ways meets the objectives of phenomenological research.

Phenomenology, as a philosophical school is based on what is given though experience, totally renouncing the idea of formulating hypotheses. What can only be given through the speech of those who experience a certain phenomenon. Thus, the researcher is not part of a specific problem, but conducts his research from questioning and, through the participants' discourses, reveals facets or ways of experiencing a certain phenomenon. ${ }^{21}$

To reach the understanding of the phenomenon, the discourses were analyzed according to the guidelines of Martins and Bicudo: ${ }^{21}$ - global reading of the total content of the discourse, in order to apprehend its global configuration; attentive re-reading in order to identify the significant affirmations of the subjects; - before the units of meanings, convergences and divergences were sought; - from the convergences/divergences, thematic categories were constructed; - a descriptive summary was made, integrating the significant statements that constitute the categories that express the meanings attributed by the volunteers of the toy library.

The research scenario was a support house for children with cancer, located in the interior/rural area/suburbs of the state of São Paulo. The inclusion criterion included being a volunteer in the toy library at the time of the research, regardless of sex, age and time of voluntary activity. Volunteers working in other areas of this institution were excluded. 
Participants included 11 volunteers of both sexes who were aged between 24 and 71 and who were performing activities in the toy library from April to June 2014. The experience of the volunteers ranged from five months to three years. All volunteers accepted to participate in the study.

The volunteers of the toy library were individually invited to participate in the study, at which time they were presented with the Informed Consent Form- TCLE and their consent was requested in accordance with Resolution 466/2012 of the National Health Council, after approval of the Research Ethics Committee (CEP), opinion number 522.942. The anonymity of the volunteers was guaranteed by using fictitious superhero names.

Participants who agreed to participate and share their experiences were interviewed using the following guiding question: "What is it like volunteering in a toy library for children with cancer?" The interviews lasted an average of $\mathbf{3 0}$ minutes were conducted in the institution's meeting room, in the presence of only the researcher and the participant,. The discourses were recorded on a digital recorder, transcribed in full and analyzed according to the recommendations of Martins and Bicudo. ${ }^{21}$

The interviews were concluded when theoretical saturation criterion was reached, that is to say, when the speeches were sufficient for the researcher to unveil the phenomenon in question, bringing clarity to what is intended to be understood. ${ }^{22,23}$

\section{RESULTS AND DISCUSSION}

After analyzing the empirical material, three thematic categories emerged: - relations with oneself, relations with the group and relations with the world, which were discussed in light of national and international literature.

\section{Relations with oneself}

Volunteer work in the toy library for children with cancer enabled voluntary workers to establish a relationship with their own selves, causing them to rethink the goal of volunteering, considering values, beliefs, world convictions, i.e., everything that moves, intimately, the human being.

For the volunteers, being with children with cancer is like donating: time, listening, affection and even an act of social responsibility.

It's very good, I'm always busy, I always have things to do,, but I think we can always find some time, sometimes I'm super tired, but it's worth it [...] (Storm) [...] volunteering makes these children forget their situation for a few moments, it makes them smile, makes them feel happier in the world. (Elektra)

However, this donation is not unilateral, i.e., only from the volunteer to the child, because the interactional aspect is also present, because the volunteers realize that they also benefit by carrying out volunteer work, as Storm highlights:
When you think of volunteer work, I think a lot about helping other people, and I think of those two, you can see who else benefitted here, I realized that the person who was helped the most was me. [...] you give a lot and you learn a lot and you are very rewarded, I think when you relate to a person, both sides, benefit you know? I think the person wins, you win, but I think when you help someone and your help is being positive, I think you win again, so it's as if you win twice and the person being helped wins alone one, which would be your help, you know? (Storm)

In a study about volunteering in the Portuguese Red Cross, the volunteer is seen as an individual capable of promoting changes in social dynamics, giving support and improving the living conditions of those they support. However, this is a twoway relationship, because at the same time that the volunteers help, they also receive since voluntary work is responsible for increasing their own quality of life. ${ }^{24}$

Volunteers perceive that child-volunteer interaction is maximized by the therapeutic process that distances children from their families, making them more receptive to new interpersonal relationships due to the need to adapt to the new reality.

[...] they are children who sometimes spend months or even more than a year there in the house, so it ends up causing them to lose a little contact with friends, with the family and this facilitates this approach of the volunteer with the child [...] it is almost inevitable, you will play, stay with them, it happens naturally... (Captain America)

Although the child-volunteer relationship is beneficial to both, volunteer involvement sometimes outweighs the environment of the support house, leading him to visit child and family during hospitalization periods.

[...] I used to go there when I could... I couldn't always visit the children in the hospital because they still had better support in the House, so to speak, there are other children, other mothers, who also end up getting very close. (Captain America)

However, not all volunteers feel prepared to interact with the child in the hospital, causing them to feel distressed.

[...] the first time I went to the hospital to see one of the hospitalized children from the house, it moved me so much, so much so that I started to avoid going there, because I saw that my emotional situation was still not prepared and after some time I began to adapt [...] (Elektra) 
The feeling of anguish also arises when, as a result of the evolution of the child's illness, it enters an inexorable path, that of death. The death of the child, besides being understood by the volunteer as a significant loss, is also an experience that contributes to the growth and maturation of the volunteer as a person.

The negative side is logical, but I also think... Despite having the little negative side, because it makes you sad a little, I think it also makes you very mature to learn to deal with loss, to learn to deal with the disease and I see death today, the disease, in a slightly different way, you know? (Storm)

A study of patients and volunteers at a support house in Philadelphia, USA, indicated that society perceives voluntary work with children with cancer as positive and special. ${ }^{25}$ On the contrary, one of the participants in this research does not have this view. The volunteer verbalizes feeling devalued.

\section{[...] I suffered a little when I talked about it to other people; I volunteer for a toy library with children with cancer. But then people said: Volunteer? Do you stay in a place that's not the best and you have sick children and you volunteer? Do you not get anything? (Iron Man)}

The devaluation of voluntary work can be due to the lack of knowledge about the tasks that are carried out and the lack of clarity regarding the importance of voluntary work for the receiving community. But with the passing of time and building interpersonal relationship between volunteers, the perspective of how to be useful to the other can change.

[...] at first I really felt very useless here. It's true, I would leave feeling sad because I did not feel like I was doing anything good to anyone because I had no experience. I thought it was going to be a more productive thing, so I expected another kind of service [...] Then I talked to a volunteer, she said "That's the way it is." (Wonder Woman)

There are volunteers who idealize work according to their academic background, setting goals to be achieved without regard to children's age/desire and experience of illness.

In Captain Marvel's statement, the perception of not having fulfilled expectations regarding volunteer work emerges and reveals that for some voluntary workers personal goals may be different from the objectives of the institution:

[...] I think it's like this, I'm going to tell you the truth, I have not found a way like this, you know? What I need, that I came in thinking about this way [...]reading and telling stories, but stories are useless because, they are not very interested [...] in fact I came here to tell stories but it is a bit difficult because of the different age groups. I would not say that everybody wants it, some want it, some do not want it, so we intend to share it, but it's difficult because the little ones sometimes hear the story and then he suddenly picks it up, runs away [...] (Captain Marvel)

It is important that volunteer work is coordinated by individuals, whether volunteers or not, who perceive the characteristics of the workers, and who encourage teamwork, which is conceptualized as conducting activities under the leadership and guidance of a coordinator, along with workers that help themselves and that have the ability to adjust to the environment. ${ }^{26,27}$

Volunteers from a support home/house were grateful for the opportunity to be able to carry out the activities and were satisfied with the tasks that were performed. ${ }^{28}$ With regard to volunteers in this study, expectations would be closer to reality if these volunteers could undergo training, elucidating the activities of volunteers. If this training were carried out by professionals with training in health and mental health, such as the nurse, it could collaborate in the adaptation of volunteers to volunteer work.

\section{Relations with the group}

The category of relations with the group - professionals, volunteers and companions - and the volunteer's discourses has made the ability to put themselves in the place of the other emerge, in addition to the various relationships that being a volunteer in a support house make possible. Volunteers are empathetic not only to children with cancer, but also to accompanying family members, as they understand that the illness of the child affects not only the sick person but the entire family structure.

We know that when a child gets sick it is not only her that gets sick, but the whole family gets sick together, because the family joins the therapeutic process together, right? [...] We hear a lot of stories from them. Everything from how the cancer was discovered or how is the treatment. So it ends up being an environment of much complicity, right? (She-Ra)

Placing oneself in someone else's place can generate, the possibility of identification or the need to leave, ${ }^{29}$ depending on the personal characteristics of each volunteer. In the statements of the volunteers of this study, it was possible to perceive that there is a significant identification with the relatives, through the solidarity to the companions, because they consider that they experience difficult moments during the treatment.

Another thing I learned in the Home/House, I had a different notion of the people who were with the children in the hospital. I have a different opinion about these people now, It is not easy to be mother or father and to stay 24 
hours just living and experiencing a monotonous situation, day after day and night after night [...] (Wonder Woman)

In this context of suffering, the various relationships that occur with all those who are involved in the support house are perceived by the volunteers as relevant and essential to the work, since they collaborate in the adaptation to the volunteer work.

\section{[...] there are other volunteers who we always learn a little} from each other's experience. I do not know if one is right, or if one is wrong, but we learn things, right? We separate, what's good for us so we can keep, and what's bad for us so we can remove [...] (Phoenix)

Volunteers from a study that performed activities with people in palliative care have reported that they continue to participate in voluntary work because the atmosphere of the group is good and because they feel part of the group. ${ }^{30}$ Iron Man also sees the volunteer group as a family.

[...] the volunteers who I met, we ended up developing a friendship [...]. We meet at some charity party or a celebration of some special date, [...] we started to feel a little like we belonged to a family. (Iron Man)

Volunteers from a meal delivery service for the elderly reported that the feeling of job satisfaction is closely linked to the human relationships with other volunteers and the professional staff who oversee the service. ${ }^{31}$

Thus, it is possible to highlight the importance of interpersonal relationships for the volunteer workers which allow the creation of meaningful connections. But volunteer work goes beyond these interpersonal relationships, enabling individuals to acquire knowledge and reflect on their values and the world they inhabit, allowing new relationships to develop.

\section{Relations with the world}

The Relations with the world category revealed new facets about being a volunteer. A priori, to perform activities in a toy library one must like to play with the children. However, it is not only this, because through relationships with children, new demands arise that allow diverse knowledge to be produced. Consequently, this production makes self-reflection possible which feeds back the volunteer work in the toy library.

Volunteers produce knowledge from experience and coexistence with others. Some characteristics are perceived when being with children, who have a chronic disease and who are in treatment and distant from the family. While they perceive healthy children and children with cancer in a similar way, there are features of the disease and the treatment that differentiate them. In the speech below, Mulan points out similar characteristics among children.
I think that the sick child is a child in the same way, when they are not in pain or under the effect of any medication that changes the behavior, they are children like any other: cheerful and happy. They play, they participate in the same way. (Mulan)

A study comparing healthy and sick children of the same age did not observe differences in psychological development, while regarding adaptation, the most healthily adapted children were children with cancer among other diseases considered chronic. ${ }^{32}$

Considering that healthy children and children with cancer have the same developmental needs, maintaining some control over their daily life allows the child to feel welcomed in the surrounding environment. In her discourse, She- Ra shows that, depending on the treatment type the child with cancer loses control of their life:

[...] I see it like this, this issue of control, not being in control of the situation, of the treatment, they don't even control their own body, right? The injection that they have to take, the chemo, it sometimes causes nausea, gives them mucositis, anyway, they don't have control in any part of the treatment. (She-Ra)

Differences between healthy children and children with cancer emerge. Another difference is the use of technical terms by children. The volunteers perceive that the child's learning about the disease also occurs through the use of technical terms, i.e., the disease runs through the child's life, given them knowledge that healthy children do not have. Due to this aspect, some volunteers believe that the child with cancer loses the purity of childhood to some degree.

[...] children play doctor, they are doctors, so they can give you anesthesia, they work, they put an IV line in you too. It's a very playful moment, it's a very playful time and they go through their own problem, the cancer itself, they go along with it like it's a game. Like, "I'm the doctor now and I'm going to give you an injection," or "I'm going to collect your spinal fluid now" they speak as if they're adults, 4 or 5 year old doctors... they can be doctors, they can being nurses, teachers, real adults, who have no disease, they become other people. I think this is a lot of fun to watch, very funny, you participate a lot. (Storm)

The volunteers admit that the child acquires different knowledge about the disease during the cancer treatment. However, sickness greatly interferes with formal education, as they play with children who, although of school age, do not go to school and therefore are not literate. Participating in school during cancer treatment can become an arduous task. 
[...] the disease disrupted literacy, disrupted attendance at school [...] So we started at the beginning, I started from the beginning, it's common sense, that the child is 10 years old, then they are literate children, who know how to read, write and count. This is not true! [...] and the illness prevented them from attending school. (Mulan)

In addition to the characteristics of children's development, pain as well as the adverse effects of medications are constant factor in the discourses of toy library volunteers. Pain emerges as an impediment to the child's presence in the toy library, however the volunteers understand play as a measure that can reduce moments of pain.

Children who had received platelet transfusions, and who were not very well. They came here and the interaction with the other children, interaction with the other people in thr house caused them to leave here with a better smile on their face, more lively, right? Because many of them come to play even in pain, right? I do not know if the pain actually goes away or if it is the perception of the pain that diminishes. (She-Ra)

American nurses working with children with cancer have described that a significant part of their workload is used to provide emotional support to the child, especially with regard to pain. Care actions which reduce painful sensations include: clarifying the procedure for the child and distraction through toys, music, and watching cartoons on television. ${ }^{25}$

Thus, working with this public implies a respect for the characteristics of children with cancer, who focus on the present moment, as they deal with illness in a positive way most of the time ${ }^{31}$

For the toy library volunteers, learning goes beyond the physical and psychological characteristics of the child. There is also the possibility of expanding knowledge in various areas of knowledge, in addition to developing new skills. In the statement below, the contact with new cultures is evident, which demands the need to learn in order to relate and respect different people.

I think there is great mutual learning on both sides! I learned a lot from going there, in every aspect, both personal, as in how to learn to deal with children, learn to deal with people, I learned other cultures, other ways to be, I learned how to respect that [...] (Storm)

Therefore, by establishing relationships with children, chaperones, support staff, and the volunteer group themselves, the volunteers create their uniqueness. ${ }^{33} \mathrm{And}$ in doing so, volunteers may encounter an unfamiliar and adverse context to what they have experienced which enables continuous self-reflection.
The individual is understood as a being who is intimately connected to the environment in which he or she lives in. Consequently, the context is important in understanding the human being and his suffering. ${ }^{33}$ Volunteers observe how children deal with the whole experience of illness and, the way they adapt, for the volunteers, it is a great discovery and a mechanism that initiates the process of self-reflection.

[...] how strong the children are. Perhaps because they do not understand exactly what they are going through, the severity of their situation. That's talking to a child up to seven years of age or so, because those who are a little older already start to understand, right? At ten, eleven years old they know what the disease is. But they become examples of overcoming, of dealing with adverse situations in life. (Iron Man)

The reflections made by the volunteers lead to varied questions. In Wonder Woman's discourse, the life-death theme emerges as intrinsic to the process of living, which is experienced by the child in a more natural way when compared to the adult.

You start to see another meaning of life, everybody has their own burden, each has their limitation, and in one way or another, we will leave this world someday, I learned how I to deal with life and death without fretting. And it's amazing, a child passes this on to you instead of an adult, who just complains, right? (Wonder Woman)

Volunteers look to themselves regarding self-reflection, rethinking beliefs, values, and principles. A study carried out with Chinese and American volunteers showed that regardless of the work itself, there are cultural differences, since Chinese volunteers were more concerned with collective demands, while Americans were more concerned with individual demands. ${ }^{34}$

In this movement of looking within oneself, volunteers perceive the suffering of the other, like the mothers of children with cancer, whose experiences are unique, permeated with suffering and fear.

[...] this observation of behavior and everything helped me a lot to understand the world. How people behave in this kind of situation, it is extreme if you think about it, because you are a mother and you have one, often a baby, how many times have I seen! A six-month-old baby, three months with cancer and ends up having to have an arm or leg amputates. I cannot even imagine what that feels like, but as soon as she reacts to it, watching people's behavior, it was also very interesting during my work. (Elektra) 
Although research with volunteers demonstrates the altruistic nature of the work, little is said about the volunteers' selfreflection process. Medical students who performed some kind of voluntary work in a hospice reported that the work had intimately transformed them, ${ }^{35}$ which suggests a process of self-reflection.

\section{CONCLUSION AND IMPLICATIONS FOR PRACTICE}

Returning to the objective of this study - to understand the meaning of being a volunteer in a toy library for children with cancer - the results showed the paths that the volunteers go through in their activities, from donation to self-reflection, encompassing diverse relationships that contribute to the self-knowledge of the individual, making it possible to review concepts, beliefs, values, according to the new times in which we live in.

It is possible to affirm that voluntary work transforms the intimacy of each volunteer. However, this internal movement is not accompanied by professionals in the institution that this research was carried out. Therefore, nurses play a fundamental role, since their training involves, as a principle, the integrality of care, which seeks to apprehend the health needs of a given group, through dialogue among those involved.

In view of this, the need to re-think the process of receiving volunteers, especially with regard to the necessary training for the development of volunteer work and the support needed to carry it out, as when employed, the company has responsibility for their physical and mental health.

The volunteers of the toy library for children with cancer of this study do not have any support from the institution, and are at risk of emotional suffering due to being in regular contact with the disease and dying process. It is recommended that volunteer workers are accompanied by mental health professionals.

The experiences of the participants of this study, volunteers of the toy library, revealed one of the facets of voluntary work with children with cancer. However, the institution welcomes other volunteers who work in other areas, not always in direct contact with children, which suggests new research with volunteers.

\section{ACKNOWLEDGMENT}

To the promotion agency of the National Council for Scientific and Technological Development - CNPq for the assistance of research, in the form of a scientific initiation grant.

\section{REFERENCES}

1. Instituto Nacional do Câncer (BR). Diagnóstico precoce do câncer na criança e no adolescente/Instituto Nacional de Câncer, Instituto Ronald McDonald. $2^{\text {a }}$ ed. Rio de Janeiro: INCA; 2011.

2. Fermo VC, Lourençatto GN, Medeiros TS, Anders JC, Souza AlJ. O diagnóstico precoce do câncer infantil: o caminho percorrido pelas famílias. Esc Anna Nery [Internet]. 2014 Jan/Mar; [cited 2014 Mar 3]; 18(1):54-9. Available from: http://www.scielo.br/scielo.php?script=sci_ar ttext\&pid=S1414-81452014000100054
3. Glickman M, Sawyers CL. Converting cancer therapies into cures: lessons from infectious diseases. Cell [Internet]. 2012 Mar; [cited 2014 Mar 3]; 148(6):1089-98. Available from: http://dx.doi.org/10.1016/j. cell.2012.02.015

4. Dias JJ, Silva APC, Freire RLS, Andrade ASA. A experiência de crianças com câncer no processo de hospitalização e no brincar. Rev Min Enferm [Internet]. 2013 Jul/Sep; [cited 2014 Mar 3]; 17(3):608-13. Available from: http://www.reme.org.br/artigo/detalhes/676

5. Ministério da Saúde (BR). Instituto Nacional do Câncer. Estimativa 2012 - Incidência de Câncer no Brasil. Rio de Janeiro: INCA;2012. [cited 2013 Jul 20]. Available from: http://portal.saude.sp.gov.br/resources/ ses/perfil/gestor/homepage/estimativas-de-incidencia-de-cancer-2012/ estimativas_incidencia_cancer_2012.pdf

6. Portaria № 55 de 24 de fevereiro de 1999 (BR). Dispõe sobre Dispõe sobre a rotina do Tratamento Fora de Domicilio no Sistema Único de Saúde - SUS. Diário Oficial da União [Internet]. Brasília (DF): Ministério da Saúde; 1999 [cited 15 Oct 2017]. Available from: http://bvsms.saude. gov.br/bvs/saudelegis/sas/1999/prt0055_24_02_1999.html

7. Cury P.Casa de Apoio aos Pacientes com Câncer do Hospital das Clínicas da Faculdade de Medicina da USP Ribeirão Preto [trabalho de conclusão de curso] [Internet]. Ribeirão Preto: Faculdade de Arquitetura e Urbanismo, Centro Universitário Barão de Mauá; 2015 [cited 2017 Dec 26]. Available from: https://issuu.com/paulacury.arq/docs/tfg__tudo_junto_

8. Silva LF, Cabral IE. O resgate do prazer de brincar da criança com câncer no espaço hospitalar. Rev Bras Enferm [Internet]. 2015 May/ Jun; [cited 2017 Mar 26]; 68(3):391-7. Available from: http://dx.doi. org/10.1590/0034-7167.2015680303i

9. Fonseca MRA, Campos CJG, Ribeiro CA, Toledo VP, Melo LL. Revelando o mundo do tratamento oncológico por meio do brinquedo terapêutico dramático. Texto Contexto Enferm [Internet]. 2015 Oct/Dec; [cited 2017 Mar 26]; 24(4):1112-20. Available from: http://www.scielo.br/pdf/tce/ v24n4/pt_0104-0707-tce-24-04-01112.pdf

10. Silva LF, Cabral IE. Cancer repercussions on play in children implications for nursing care. Texto Contexto Enferm [Internet]. 2014 Oct/Dec; [cited 2017 Oct 2]; 23(4):935-43. Available from: http://dx.doi. org/10.1590/0104-07072014002380013

11. Melo LL, Valle ERM. A brinquedoteca como possibilidade para desvelar o cotidiano da criança com câncer em tratamento ambulatorial. Rev Esc Enferm USP [Internet]. 2010; [cited 2014 Mar 3]; 44(2):517-25. Available from: http://www.scielo.br/pdf/reeusp/v44n2/39.pd

12. Lei n. 9.608 de 18 de fevereiro de 1998 (BR). Dispõem sobre o serviço voluntario e dá outras previdências. Diário Oficial da União [Internet] Brasília (DF): Ministério da Saúde; 1998 [cited 2014 Mar 3]. Available from: http://www.planalto.gov.br/ccivil_03/leis/L9608.htm

13. Caldana ACF, Souza LB, Camiloto CM. Sentidos das ações voluntárias: desafios e limites para a organização do trabalho. Psicol Soc [Internet] 2012; May/Aug; [cited 2017 Mar 26]; 24(1):170-7. Available from: http:// www.scielo.br/pdf/psoc/v24n1/19.pdf

14. Cavalcante CE. Motivação no trabalho voluntário: delineamento de estudos no Brasil. Rev Est CEPE [Internet]. 2013 Jul/Dec; [cited 2017 Mar 26]; 38:161-82. Available from: https://online.unisc.br/seer/index. php/cepe/article/view/3719/3125

15. Catão FAS. A influência do trabalho voluntário na qualidade de vida dos voluntários da cidade de Caminas Grande - PB [Trabalho de conclusão de curso]. [Internet]. Campina Grande: Faculdade de Administração, Universidade Estadual da Paraíba - UEPB; 2015 [cited 2017 Dec 26]. Available from: http://dspace.bc.uepb.edu.br/jspui/ bitstream/123456789/8812/1/PDF\%20-\%20Fabiana\%20Almeida\%20 de\%20Souza\%20Cat\%C3\%A3o.pdf

16. Muckaden MA, Pandya SS. Motivation of volunteers to work in palliative care setting: a qualitative study. Indian J Palliat Care [Internet]. $2016 \mathrm{Jul} /$ Sep; [cited 2017 Oct 16]; 22(33):348-53. Available from: https://www. ncbi.nlm.nih.gov/pmc/articles/PMC4973499/

17. Jensen LG, Lou S, Aagaard J, Vaeggemose U. Community families: a qualitative study of families who volunteer to support persons with severe mental illness. Int J Soc Psychiatry [Internet]. 2016 Dec; [cited 2017 Oct 16]; 63(1):33-9. Available from: http://journals.sagepub.com/ doi/pdf/10.1177/0020764016674346 
18. Heidegger M. Ser e tempo. Campinas: Editora da Unicamp/Vozes; 2012.

19. Melo LL. Fenomenologia e pesquisa fenomenológica. [trabalho apresentado a disciplina Fenômeno grupal em contextos institucionais do curso de Pós-Graduação em Psicologia]. Ribeirão Preto: Faculdade de Filosofia, Ciências e Letras de Ribeirão Preto, Universidade de São Paulo; 1997. (mimeo)

20. Giorgi A. Phenomenology and psychological research. Pittsburgh: Duchesne Universiy Press; 1985.

21. Martins J, Bicudo MAV. Pesquisa qualitativa em Psicologia: fundamentos e recursos básicos. São Paulo: Moraes; 2004.

22. Fontanella BJB, Luchesi BM, Saidel MGB, Ricas J, Turato ER, Melo DM. Amostragem em pesquisas qualitativas: proposta de procedimentos para constatar saturação teórica. Cad Saúde Pública [Internet]. 2011 Feb; [cited 2017 Dec 26]; 27(2):389-94. Available from: http://www.scielo.br/scielo.php?script=sci_arttext\&pid=S0102-311X2011000200020

23. Detoni AR, Paulo RM. A organização dos dados da pesquisa em cena. In: Bicudo MAV. Fenomenologia: confrontos e avanços. São Paulo: Cortez Editora; 2000.

24. Fernandes A, Reis Mourão P. Para uma abordagem institucionalista do voluntariado - o caso do voluntário da Cruz Vermelha portuguesa. Innovar [Internet]. 2012; [cited 2014 Apr 15];22(43):45-54. Available from: http://www.scielo.org.co/scielo.php?script=sci_abstract\&pid=S0121$50512012000100005 \& \operatorname{lng}=e n \& n r m=i s o \& t \mid n g=p t$

25. Weinstein AG, Henrich CC. Psychological interventions helping pediatric oncology patients cope with medical procedures: a nursecentered approach. Eur J Oncol Nurs [Internet] 2013 Dec; [cited 2014 Apr 15]; 17(6):726-31. Available from: http://www.ejoncologynursing. com/article/S1462-3889(13)00048-3/abstract

26. Kalisch $B J$, Labelle $A E$, Boqin $X$. Nursing teamwork and time to respond to call lights: an exploratory study. Rev Latino Am Enferm [Internet]. $2013 \mathrm{Jan} / \mathrm{Feb}$; [cited 2014 Apr 15]; 21 (no.esp):242-9. Available from: http://www.scielo.br/scielo.php?script=sci_arttext\&pi $\mathrm{d}=$ S0104-11692013000700030

27. Almeida LMWS, Santos RM. The Nursing work and the construction of a democratic society. Rev Bras Enferm [Internet]. 2017 Sep/ Oct; [cited 2017 Oct 18]; 70(5):896-7. Available from: http://dx.doi. org/10.1590/0034-7167.2017700501
28. Leventhal DH, Hustinx L, Handy F. What Money Cannot Buy: The Distinctive and Multidimensional Impact of Volunteers. J Community Pract [Internet]. 2011 Abr; [cited 2014 Apr 15]; 19(2):138-58. Available from: https://www.researchgate.net/publication/233374835_What Money_Cannot_Buy_The_Distinctive_and_Multidimensional_Impact_ of_Volunteers

29. Rodrigues KM, Citadin MW, Cruz JAW, Araújo DP, Rocha DT. Voluntariado: um estudo bibliométrico e sóciomético da produção científica da temática da revista voluntas (1997-2012). Rev Perspect Contemp [Internet]. $2014 \mathrm{Jul} / \mathrm{Dec}$; [cited 2014 Apr 18]; 9(2):150-66. Available from: http://revista.grupointegrado.br/revista/index.php/ perspectivascontemporaneas/article/view/1452/620

30. Claxton-Oldfield S, Claxton-Oldfield J. Should I stay or should go: a study os a hospice palliative care volunteer satisfaction and retention. Am J Hosp Palliat Care [Internet]. 2012 Nov; [cited 2014 Apr 18]; 29(7):525-30. Available from: https://www.ncbi.nlm.nih.gov/ pubmed/22241460

31. Yanagisawa $\mathrm{H}$, Sakakibara $\mathrm{H}$. Factors affecting satisfaction levels of Japonese volunteers in meal delivery services for the elderly. Public Health Nurs [Internet]. 2008 Sep/Oct; [cited 2014 Apr 18]; 25(5):471-9. Available from: https://www.ncbi.nlm.nih.gov/pubmed/18816364

32. Wechsler AM, Sánchez-Iglesias I. Psychological adjustment of children with cancer as compared with healthy children: a meta-analysis. Eur $J$ Cancer Care (Engl) [Internet]. 2013 May; [cited 2014 Apr 27]; 22(3):31425. Available from: https://www.ncbi.nlm.nih.gov/pubmed/23279127

33. Jurdi APS, Amiralian MLTM. Ética do cuidado: a brinquedoteca como espaço de atenção a crianças em situação de vulnerabilidade. Interface (Botucatu) [Internet]. 2013 Apr/Jun; [cited 2014 Apr 27]; 17(45):275-85. Available from: http://dx.doi.org/10.1590/S1414-32832013005000009

34. Liu ESC, Ching CWL, Wu J.Who is a volunteer? A cultural and temporal exploration of volunteerism. J Hum Behav Soc Environ [Internet]. 2017 Mar; [cited 2017 Oct 17]; 27(6):530-45. Available from: http://dx.doi.or g/10.1080/10911359.2017.1295715

35. Mott ML, Gorawara-Bhat R, Marschke M, Levine S. Medical students as hospice volunteers: reflections on an early experiential training program in end-of-life care education. J Palliat Med [Internet]. 2014 Jun; [cited 2014 Apr 27]; 17(6):696-700. Available from: https://www.ncbi.nlm.nih. gov/pubmed/24754869 